\title{
O COMÉRCIO NO ÂMBITO DO MERCOSUL
}

\author{
Sérvulo Vicente Moreira*
}

\section{Resumo}

Um dos principais objetivos da integração de mercados é a criação de comércio, viabilizado pela firma individual, a qual tende a especializar-se em termos de tecnologia e de mão-de-obra para atender à nova demanda. Neste trabalho, será apresentado o incremento de empresas brasileiras exportadoras para o MERCOSUL, a evolução de suas exportações em termos de valor, a dinâmica da quantidade de empregados e a evolução dos seus graus de escolaridade e salários nessas empresas. A análise foi realizada com foco no país, no estado e no município onde essas empresas exportadoras desenvolvem suas atividades. A dinâmica das empresas exportadoras tem impactado a economia brasileira no que concerne às melhorias do setor produtivo, à relação intrafirma, ao eficiente uso dos insumos nacionais e importados bem como à especialização da mão-de-obra, proporcionando, assim, a melhoria do bem-estar. Esses aspectos demonstram o quanto o MERCOSUL se tornou e se tornará importante para a economia brasileira.

Palavras-chave: Mercosul. Integração regional. Empresas brasileiras exportadoras. Evolução comercial.

\section{O comércio}

As vantagens proporcionadas pelo comércio internacional foram demonstradas pelos economistas clássicos e neoclássicos, não só pela

* IPEA - Técnico de Planejamento e Pesquisa

Univ. Rel. Int., Brasília, v. 5, n. 1/2, p. 67-95, jan./dez. 2007 
forma mais eficiente de se aproveitar os recursos, mas, também, por aproximar os países, permitindo que práticas e técnicas fossem absorvidas pelas partes envolvidas.

Durante a década de 50, essas premissas influenciaram a política de integração. Foram implantados blocos econômicos como, em 1951, a Comunidade Européia do Carvão e do Aço - CECA, que propiciou a instituição em 1957 da Comunidade Econômica Européia - CEE (Mercado Comum Europeu), a qual, a partir de 1992, tornou-se União Européia - UE. Desde os anos 60 do século passado, o mundo assiste a proliferação de blocos econômicos integracionistas.

A América Latina participou desse processo de integração com blocos como: Associação Latina Americana de Comércio - ALALC; Grupo Andino; Mercado da Comunidade do Caribe - CARICOM; Mercado Comum Centro-Americano; Associação Latino-Americana de Integração - ALADI (ex - ALALC); e outros blocos menores para alguns setores específicos.

O objetivo dos blocos econômicos é aproximar os países comercialmente, por meio da redução gradual de tarifas, estabelecer medidas comuns aos países membros, melhorar as economias domésticas e a qualidade de vida da população.

Os blocos integracionistas, a partir dos anos 60, foram surgindo altamente dependentes das orientações políticas e econômicas dos seus países membros. Observou-se que muitos dos países integrantes desses novos blocos não possuíam estruturas favoráveis à viabilização desse sistema de integração, bem como a conjuntura internacional não acomodava esse tipo de bloco. Nesses casos, os países mantiveram como prioridade a busca de soluções para seus problemas socioeconômicos internos.

Considerando aspectos históricos dos países latino-americanos - rivalidade na concorrência comercial no tocante às suas vendas externas, 68 Univ. Rel. Int., Brasília, v. 5, n. 1/2, p. 67-95, jan./dez. 2007 
comércio bilateral com diferentes parceiros de outros continentes, diferenças estruturais abrangendo esferas socioeconômicas, políticas e culturais -, até o início dos anos 90, esses processos integracionistas não haviam alcançado parte dos resultados esperados, sobretudo entre outros fatores, pela falta de maior tradição comercial entre as diferentes economias.

Ao mesmo tempo, a ocorrência da ALADI apontou para uma via de integração melhor sucedida em relação às anteriores. Pode-se afirmar que tanto a ALADI como a ALALC pavimentaram o caminho para o Mercosul, à medida que lançaram bases para a integração na América Latina.

Em 1991, foi constituído o Mercado Comum do Sul Mercosul, com a assinatura do Tratado de Assunção. Formado, na época, por Argentina, Brasil, Paraguai e Uruguai, admitia outra dinâmica comercial. Foram considerados aspectos como: posição estratégica da região; fortalecimento da região frente ao mercado internacional; e criação de comércio entre os países membros do bloco. Isso proporcionaria, ainda, melhoria da qualidade de vida de seus habitantes.

Um acordo de comércio preferencial visa a incrementar o bemestar de seus países membros, possibilitando-lhes melhor aproveitamento dos benefícios estáticos e dinâmicos decorrentes tanto de um comércio mais diversificado e livre quanto de maior integração dos mercados. Esses benefícios podem ocorrer por meio de maiores fluxos de comércio e de investimento, sobretudo em infra-estrutura - transportes, energia, comunicações e telecomunicações -, objetivando aumentar o crescimento do fluxo comercial.

As economias latino-americanas, durante os anos 80, iniciaram a reforma de suas políticas comerciais, abandonando, gradualmente, os sistemas protecionistas ainda restantes do período de substituição de importações, para se tornarem economias abertas. Essa abertura teve um 
impacto positivo na estrutura da indústria e do comércio exterior dos países integrantes. Possibilitou expansão da produção, criação de comércio beneficiando empresas, mercados e consumidores, promoveu a criação de vários postos de trabalho com qualificações diferenciadas, inseriu e está inserindo, de forma dinâmica, a economia regional na economia mundial, por meio de processos de aproximação e do desempenho de novas atividades, contribuindo, assim, para o desenvolvimento socioeconômico regional.

O Mercosul foi alcançando maior destaque à medida que os países foram empenhando-se em aproximar-se comercialmente - fazendo, de modo gradual, o processo de liberalização comercial, ou seja, redução gradual das tarifas incidentes sobre as importações - e outros entraves ao comércio externo foram retirados. Observaram-se alterações contínuas nas economias desses países, desde as perspectivas de grandes empresas até as de pequenas e médias empresas, sendo que novos aspectos microeconômicos foram surgindo para melhor alcançar os propósitos estabelecidos ao novo mercado potencial. Esses esforços objetivavam incrementar exportações, reforma comercial, integração regional, novos mercados para vendas externas e propiciar melhoria na qualidade de vida da população dos países integrantes.

O comércio do Brasil com os outros três países membros do bloco integracionista, no período de 1980 a 2001, encontra-se descrito em quadros apresentados a seguir, neste artigo. Nesses quadros, pode-se ver que a instituição do Mercosul gerou incremento comercial entre os países e facilitou a criação de comércio.

\section{Argentina}

O país dispõe de muitos recursos naturais e possui elevada vantagem comparativa no setor agrícola, sendo, tradicionalmente, produtor de 
carnes e cereais. Seu solo é rico em minérios. Em petróleo, a Argentina é auto-suficiente.

A economia passou por um forte período de desindustrialização e de estagnação econômica, durante os anos setenta e oitenta do século passado, como reflexo da política interna e da recessão mundial. No início dos anos noventa, vieram os indícios de recuperação. O setor industrial é formado por indústrias nacionais e multinacionais, atraídas pelo cenário econômico que apresentava possibilidades de crescimento. Na época, grande parte dos investimentos foi direcionada ao setor alimentício.

O estabelecimento do Mercosul, em 1991, possibilitou ao país estender suas vendas externas aos países vizinhos, integrantes desse novo bloco. Durante essa década, houve um incremento das exportações argentinas, sobretudo de produtos manufaturados, do setor agrícola e industrial e, também, de derivados de petróleo. Nesse novo impulso comercial, o Brasil tornou-se o maior parceiro comprador de produtos argentinos.

A Argentina conseguiu, na década de 90, incrementar suas exportações devido a fatos como a liberalização comercial, a valorização da moeda e o crescimento da demanda interna. Ademais, para viabilizar a modernização do parque industrial interno, foram realizadas importações de vários componentes, sobretudo de bens de capital que representaram, em 1994, cerca de 44\% do total das importações.

Aspectos como discordância, rivalidade e concorrência comercial entre o Brasil e a Argentina foram aos poucos sendo esquecidos, possibilitando cooperação sólida e estreitamento de laços econômicos.

Durante determinado período, na Argentina, acentuou-se a dependência de poupança externa. Houve dificuldade de reversão e, por conseguinte, fortes efeitos sobre o comércio externo do país. 
Mesmo assim, nas últimas décadas, o país alcançou progressos consideráveis em sua institucionalização democrática e, inclusive, na modernização da economia, resultado, em grande parte, da abertura comercial e de um acentuado processo de investimentos, tanto para a produção de bens como para a prestação de serviços.

Cabe destacar a importância, para a Argentina, de sua relação estratégica com o Brasil e da construção de um Mercosul mais consolidado, que possa ser visto pela qualidade de suas regras e pela eficácia de seus compromissos, num âmbito externo regional mais favorável para as transformações políticas, econômicas e sociais, necessárias a todos seus membros.

\section{Comércio entre Brasil e Argentina}

As exportações do Brasil para a Argentina cresceram de US\$ 645,1 milhões, em 1990, para US\$ 5,0 bilhões, em 2001, o que representa um aumento de 775,4\%. Quanto às importações brasileiras da Argentina, o crescimento, também, foi acentuado. Em 1990, o Brasil importou US\$ 1.4 bilhões e, em 2001, US\$ 6,2 bilhões, o que evidencia um crescimento percentual de 443,5\%. E, claramente, vê-se o progressivo aumento no fluxo comercial desde a implementação do Mercosul.

Nota-se que as importações brasileiras cresceram mais que as exportações. Assim, o Brasil passou a ter um saldo comercial negativo com a Argentina com freqüência cada vez maior, a partir de 1986, ano da primeira relação deficitária do Brasil com a Argentina. 


\section{Quadro I \\ Comércio Brasil Argentina}

\begin{tabular}{|c|c|c|c|c|c|}
\hline \multicolumn{6}{|c|}{ COMÉRCIO BILATERAL BRASIL-ARGENTINA } \\
\hline ANO & $\begin{array}{c}\text { Exportação } \\
\text { A }\end{array}$ & $\begin{array}{c}\text { Importação } \\
\text { B }\end{array}$ & Saldo & $\begin{array}{l}\text { Corrente de } \\
\text { Comércio } \\
(\mathrm{A}+\mathrm{B})\end{array}$ & $\begin{array}{c}\text { Cobertura } \\
\text { (A/B) }\end{array}$ \\
\hline 1980 & 1.091 .521 .352 & 756.500 .256 & 335.021 .096 & 1.848 .021 .608 & 1,44 \\
\hline 1981 & 880.225 .916 & 586.579 .957 & 293.645 .959 & 1.466 .805 .873 & 1,5 \\
\hline 1982 & 666.362 .765 & 550.228 .901 & 116.133 .864 & 1.216 .591 .666 & 1,21 \\
\hline 1983 & 654.626.915 & 358.068.969 & 296.557.946 & 1.012 .695 .884 & 1,83 \\
\hline 1984 & 853.110 .080 & 510.898 .352 & 342.211 .728 & \begin{tabular}{|l|l}
1.364 .008 .432 \\
\end{tabular} & 1,67 \\
\hline 1985 & \begin{tabular}{|l}
548.237 .398 \\
\end{tabular} & 468.865 .172 & 79.372 .226 & 1.017 .102 .570 & 1,17 \\
\hline 1986 & 678.336.014 & 736.988 .420 & -58.652 .406 & 1.415.324.434 & 0,92 \\
\hline 1987 & 831.782 .372 & 574.687 .755 & 257.094 .617 & \begin{tabular}{|l|}
1.406 .470 .127 \\
\end{tabular} & 1,45 \\
\hline 1988 & 979.385.445 & 707.104.076 & 272.281.369 & 1.686.489.521 & 1,39 \\
\hline 1989 & 722.114 .851 & 1.238 .985 .251 & -516.870 .400 & 1.961 .100 .102 & 0,58 \\
\hline 1990 & 645.139 .867 & 1.399 .680 .430 & -754.540 .563 & 2.044.820.297 & 0,46 \\
\hline 1991 & \begin{tabular}{|l}
1.476 .170 .289 \\
\end{tabular} & \begin{tabular}{|l}
1.614 .679 .799 \\
\end{tabular} & -138.509 .510 & \begin{tabular}{|l|}
3.090 .850 .088 \\
\end{tabular} & 0,91 \\
\hline 1992 & 3.039.983.798 & 1.731.625.482 & 1.308.358.316 & 4.771.609.280 & 1,76 \\
\hline 1993 & 3.658.779.257 & 2.717.266.437 & 941.512 .820 & 6.376.045.694 & 1,35 \\
\hline 1994 & 4.135 .864 .352 & 3.661 .966 .005 & 473.898 .347 & 7.797.830.357 & 1,13 \\
\hline 1995 & 4.041 .135 .877 & 5.591.392.742 & $\begin{array}{c}- \\
1.550 .256 .865\end{array}$ & 9.632.528.619 & 0,72 \\
\hline 1996 & 5.170 .031 .615 & 6.805.466.613 & $\begin{array}{c}- \\
1.635 .434 .998 \\
\end{array}$ & 11.975.498.228 & 0,76 \\
\hline 1997 & 6.767.277.197 & 7.941.285.817 & $\begin{array}{c}- \\
1.174 .008 .620 \\
\end{array}$ & 14.708.563.014 & 0,85 \\
\hline 1998 & 6.748.203.941 & 8.034 .172 .879 & 1.285.968.938 & 14.782.376.820 & 0,84 \\
\hline 1999 & 5.363.954.061 & 5.812.388.711 & -448.434 .650 & 11.176 .342 .772 & 0,92 \\
\hline 2000 & 6.232 .745 .675 & 6.843.457.618 & -610.711 .943 & 13.076.203.293 & 0,91 \\
\hline 2001 & 5.002.488.509 & 6.206.864.556 & 1.204.376.047 & 11.209.353.065 & 0,81 \\
\hline
\end{tabular}

Fonte: SECEX. Elaboração: IPEA

\section{Paraguai}

As exportações paraguaias constituem-se de produtos agrícolas. O país não participou, significativamente, de um processo de substituição de importações como seus vizinhos. Durante o período compreendido entre os anos cinqüenta e oitenta do último século, baseou-se 


\section{O comércio no âmbito do Mercosul}

num modelo de crescimento voltado para as exportações, apoiado nas vendas externas de produtos agrícolas, pecuários e florestais. Esse desenvolvimento foi, amplamente, amparado por outros eventos que ajudaram a economia como: a construção das represas de Itaipu e de Yaciretá, e o comércio de fronteira, que tinha um pesado componente ilegal.

Na década de oitenta, esse modelo esgotou-se e o país não voltou a crescer. A esse fato está associada a crise rural que atingiu metade da população do país. O Paraguai não passou por desequilíbrios macroeconômicos como os outros países da região, particularmente a Argentina e o Brasil. Mas, também, não teve ciclos de crescimento semelhantes aos desses países. Ainda na década de 80, o governo paraguaio reduziu o seu déficit, sendo as empresas públicas saneadas e as taxas múltiplas de câmbio unificadas, liberalizando o mercado de trocas externas.

Em 1989, a ditadura militar chegou ao término. Em junho de 1992, foi promulgada uma nova constituição, e as novas eleições foram realizadas em maio do mesmo ano.

Com vistas a aumentar a capacidade de pagamentos externos e a manter a reexportação do setor de triangulação e as finanças públicas em equilíbrio, o governo paraguaio não realizou grandes investimentos e manteve o dólar sobrevalorizado, mantendo a depreciação cambial. Ademais, o país já dependia, consideravelmente, da demanda externa por seus produtos agrícolas.

A triangulação comercial no Paraguai mantém boa parte do fluxo comercial do país e tem origem fora da região, destinando-se ao Mercosul. O estabelecimento de uma tarifa comum no âmbito do Mercosul desestimula essa triangulação. A pequena indústria local, basicamente artesanal, está prejudicada pela concorrência regional e tem dificuldades para aproveitar o incremento da capacidade de negociação fora dessa zona. 
Poucos setores produtivos da economia conseguiram beneficiar-se com a integração regional.

As atividades econômicas paraguaias concentram-se na região oriental do país, onde está Assunção. Atualmente, 44\% da população vivem na área rural.

\section{Comércio entre Brasil e Paraguai}

Em quase todo o período, o Brasil manteve uma situação superavitária com o Paraguai, e, durante a década de 90, nota-se forte aumento no fluxo comercial na época em que o Brasil mantinha sua moeda valorizada em relação ao dólar. Esse fluxo diminuiu junto com a desvalorização cambial.

\section{Quadro II \\ Comércio Brasil Paraguai}




\begin{tabular}{|c|c|c|c|c|c|}
\hline \multicolumn{7}{|c|}{ COMÉRCIO BILATERAL BRASIL-PARAGUAI } \\
\hline ANO & $\begin{array}{c}\text { Exportação } \\
\text { A }\end{array}$ & $\begin{array}{c}\text { Importação } \\
\text { B }\end{array}$ & Saldo & $\begin{array}{c}\text { Corrente de } \\
\text { Comércio } \\
\text { (A+B) }\end{array}$ & $\begin{array}{c}\text { Cobertura } \\
\text { (A/B) }\end{array}$ \\
\hline 1980 & 409.227 .631 & 91.471 .653 & 317.755 .978 & 500.699 .284 & 4,47 \\
\hline 1981 & 449.604 .823 & 191.470 .073 & 258.134 .750 & 641.074 .896 & 2,35 \\
\hline 1982 & 324.438 .680 & 167.017 .978 & 157.420 .702 & 491.456 .658 & 1,94 \\
\hline 1983 & 233.407 .865 & 32.166 .182 & 201.241 .683 & 265.574 .047 & 7,26 \\
\hline 1984 & 332.690 .219 & 39.978 .474 & 292.711 .745 & 372.668 .693 & 8,32 \\
\hline 1985 & 301.713 .253 & 74.850 .282 & 226.862 .971 & 376.563 .535 & 4,03 \\
\hline 1986 & 289.343 .837 & 150.127 .246 & 139.216 .591 & 439.471 .083 & 1,93 \\
\hline 1987 & 287.992 .937 & 65.856 .784 & 222.136 .153 & 353.849 .721 & 4,37 \\
\hline 1988 & 341.964 .366 & 117.371 .563 & 224.592 .803 & 459.335 .929 & 2,91 \\
\hline 1989 & 322.931 .634 & 358.828 .403 & -35.896 .769 & 681.760 .037 & 0,9 \\
\hline 1990 & 380.483 .806 & 332.777 .826 & 47.705 .980 & 713.261 .632 & 1,14 \\
\hline 1991 & 496.114 .094 & 219.586 .672 & 276.527 .422 & 715.700 .766 & 2,26 \\
\hline 1992 & 543.319 .917 & 194.998 .173 & 348.321 .744 & 738.318 .090 & 2,79 \\
\hline 1993 & 952.319 .828 & 275.608 .933 & 676.710 .895 & 1.227 .928 .761 & 3,46 \\
\hline 1994 & 1.053 .623 .226 & 352.454 .640 & 701.168 .586 & 1.406 .077 .866 & 2,99 \\
\hline 1995 & 1.300 .733 .200 & 514.654 .194 & 786.079 .006 & 1.815 .387 .394 & 2,53 \\
\hline 1996 & 1.324 .582 .113 & 552.239 .495 & 772.342 .618 & 1.876 .821 .608 & 2,4 \\
\hline 1997 & 1.406 .682 .916 & 517.517 .938 & 889.164 .978 & 1.924 .200 .854 & 2,72 \\
\hline 1998 & 1.249 .436 .209 & 351.167 .978 & 898.268 .231 & 1.600 .604 .187 & 3,56 \\
\hline 1999 & 744.284 .058 & 259.808 .034 & 484.476 .024 & 1.004 .092 .092 & 2,86 \\
\hline 2000 & 831.784 .961 & 351.305 .611 & 480.479 .350 & 1.183 .090 .572 & 2,37 \\
\hline 2001 & 720.199 .378 & 300.206 .801 & 419.992 .577 & 1.020 .406 .179 & 2,4 \\
\hline
\end{tabular}

Fonte: SECEX. Elaboração: IPEA

\section{Uruguai}

A primeira metade dos anos 80 foi um período de dificuldades para o país, com excessiva dependência das exportações baseadas em dois produtos, carne bovina e lã. A inflação e o controle monetário mantiveram a moeda em níveis irreais. Taxas de crescimento baixas ou negativas criaram problemas para o setor financeiro e reduziram a renda fiscal. Houve dificuldades para os cortes no déficit orçamentário, condição para apoio do FMI. Tal fato aconteceu em quase todos os países da América Latina que foram obrigados a renegociar suas dívidas. 
Em grande parte, a situação do continente latino-americano foi resultado dos desajustes econômicos dos países desenvolvidos, durante a década de 70, e da recessão internacional, nos anos 80, cujos efeitos foram negativos para o crescimento dessas economias.

De 1974 a 1980, o PIB do país cresceu numa média de 4,7\% ao ano, quando o governo Uruguaio optou por maior inserção do país no mercado internacional, mas foi obrigado a adotar minidesvalorizações da taxa de câmbio. Isso resultou em sobrevalorização do Peso e em declínio da competitividade das exportações. De 1982 a 1984, a economia foi fortemente atingida pela recessão mundial.

A retomada do crescimento uruguaio começou em 1985, acelerando em 1986 e 1987, por meio do incremento das exportações. Os anos 1988 e 1989 foram de estagnação devido à manutenção de controle nas políticas monetária e fiscal e a uma prolongada seca, que afetou o gado. A produção era mais baixa no final da década do que em 1980.

Na década de 90, os elevados preços do petróleo e apreciações do Cruzeiro brasileiro e do Austral argentino inibiram as metas econômicas do governo da época.

\section{Comércio entre Brasil e Uruguai}

De 1990 a 2001, o comércio bilateral entre Brasil e Uruguai evoluiu de forma acentuada. Esse período foi marcado por saldos comerciais positivos e negativos dos dois lados, conforme observado na tabela a seguir.

As vendas brasileiras para o Uruguai aumentaram de US\$ 294,6 milhões, em 1990, para US\$ 641 milhões, em 2001, com um crescimento percentual de $117 \%$. No tocante às exportações, estas decresceram de US\$ 587,1 milhões, em 1990, para US\$ 503,0 milhões, em 2001, com um decréscimo de 14,3\% em termos percentuais. 


\section{Quadro III \\ Comércio Brasil Uruguai}

\begin{tabular}{|c|c|c|c|c|c|}
\hline \multicolumn{6}{|c|}{ COMÉRCIO BILATERAL BRASIL-URUGUAI } \\
\hline ANO & $\begin{array}{c}\text { Exportação } \\
\text { A }\end{array}$ & $\begin{array}{c}\text { Importação } \\
\text { B }\end{array}$ & Saldo & $\begin{array}{l}\text { Corrente de } \\
\text { Comércio } \\
\text { (A+B) }\end{array}$ & $\begin{array}{l}\text { Cobertura } \\
\text { (A/B) }\end{array}$ \\
\hline 1980 & 310.691 .027 & 196.052 .889 & 114.638 .138 & 506.743 .916 & 1,58 \\
\hline 1981 & 373.157 .598 & 178.328 .227 & 194.829.371 & 551.485 .825 & 2,09 \\
\hline 1982 & 137.795 .425 & 151.174 .491 & -13.379 .066 & 288.969 .916 & 0,91 \\
\hline 1983 & 104.024 .430 & 130.815 .904 & -26.791 .474 & 234.840 .334 & 0,8 \\
\hline 1984 & 135.840 .396 & 123.020 .376 & 12.820 .020 & 258.860 .772 & 1,1 \\
\hline 1985 & 140.350 .052 & 140.036 .935 & 313.117 & 280.386 .987 & 1 \\
\hline 1986 & 202.618 .138 & 300.994 .917 & -98.376 .779 & 503.613 .055 & 0,67 \\
\hline 1987 & 267.769 .814 & 247.477 .185 & 20.292 .629 & 515.246 .999 & 1,08 \\
\hline 1988 & 321.596 .901 & 313.911 .576 & 7.685 .325 & 635.508 .477 & 1,02 \\
\hline 1989 & 334.670 .736 & 596.060 .854 & $\begin{array}{c}- \\
261.390 .118\end{array}$ & 930.731 .590 & 0,56 \\
\hline 1990 & 294.620 .606 & 587.093 .198 & $\begin{array}{c}- \\
292.472 .592\end{array}$ & 881.713 .804 & 0,5 \\
\hline 1991 & 337.068 .218 & 434.103 .071 & -97.034 .853 & 771.171 .289 & 0,78 \\
\hline 1992 & 514.165 .568 & 301.939 .813 & 212.225 .755 & 816.105 .381 & 1,7 \\
\hline 1993 & 775.810 .556 & 385.378 .970 & 390.431 .586 & 1.161 .189 .526 & 2,01 \\
\hline 1994 & 731.988 .403 & 568.849 .752 & 163.138 .651 & 1.300 .838 .155 & 1,29 \\
\hline 1995 & 811.899 .145 & 737.876 .973 & 74.022 .172 & 1.549 .776 .118 & 1,1 \\
\hline 1996 & 810.668 .220 & 943.841 .218 & $\begin{array}{c}- \\
133.172 .998\end{array}$ & 1.754 .509 .438 & 0,86 \\
\hline 1997 & 869.979 .145 & 967.339 .679 & -97.360 .534 & 1.837.318.824 & 0,9 \\
\hline 1998 & 880.593 .693 & 1.042 .362 .034 & $\begin{array}{c}- \\
161.768 .341\end{array}$ & 1.922 .955 .727 & 0,84 \\
\hline 1999 & 669.633.551 & 646.710 .542 & 22.923 .009 & 1.316 .344 .093 & 1,04 \\
\hline 2000 & 668.539.109 & 601.501 .182 & 67.037 .927 & 1.270 .040 .291 & 1,11 \\
\hline 2001 & 640.967 .518 & 502.929 .778 & 138.037 .740 & 1.143.897.296 & 1,27 \\
\hline
\end{tabular}

Fonte: SECEX. Elaboração: IPEA 


\section{Brasil}

A década de 80 iniciou-se com o crescimento explosivo da crise da dívida externa, sem diretrizes econômicas quanto à definição de investimentos. A queda dos investimentos refletiu, sobretudo, na qualidade e na forma, com aumento da construção civil e redução dos investimentos em máquinas e equipamentos. A crise foi acompanhada de drástica redução de recursos externos, e os programas de substituição de importações e de estímulo às exportações estavam, ainda, desenvolvendo-se.

O referido período foi, também, marcado pela alta nos preços do petróleo e pela elevação das taxas de juros internacionais. Nesse novo cenário, procuraram-se vários ajustes macroeconômicos para a economia brasileira.

Concomitantemente, a crise internacional que se instalou refletiu, de imediato, na economia doméstica, acentuando forte protecionismo dos países industrializados com suas importações, barateamento das exportações brasileiras e a falta de financiamento externo, de credibilidade dos credores e de recursos para minorar os desequilíbrios do balanço de pagamentos.

Ocorreram, no país, nessa época, uma combinação de inflação galopante com estagnação econômica e algumas tentativas para superar a crise instalada, percebida em seu caráter fiscal e social e no aspecto relacionado ao crescimento.

Foi colocada em prática uma política de contenção salarial, bem como de incremento da arrecadação, de controle de gastos do governo, de elevação das taxas de juros internas e de contração da liquidez real. 
Houve, também, queda dos preços relativos da agricultura, em 1981, ocasionada, simultaneamente, por um aumento da safra de vários produtos de abastecimento interno e por um declínio nos preços internacionais dos produtos exportáveis.

Durante a segunda metade da década de 80 , as atenções econômicas concentraram-se no combate à inflação. Os planos de estabilização adotados no período de 1981 a 1984 promoveram o ajustamento externo da economia doméstica, mas não conseguiram evitar o aumento do processo inflacionário.

Destacam-se, nesse sentido, os cansativos programas de ajustamento (foram estabelecidos três programas de estabilização: o Plano Cruzado, de 28 de fevereiro de 1986; o Plano Bresser, de 12 de junho de 1987; e o Plano Verão, de 14 de janeiro de 1989), que, apesar de apresentarem diferentes características, não alcançaram o resultado almejado.

Em meados de 90, percebia-se a necessidade de uma liberalização comercial por meio da redução de barreiras protecionistas, tanto tarifárias como não tarifárias, e da importação de inovações tecnológicas aspectos fundamentais para se traçar uma estratégia de industrialização.

Com a implementação do plano Real e com a estabilidade econômica, evidenciou-se um novo perfil tecnológico da indústria brasileira, o que propiciou maior inserção de produtos brasileiros no mercado internacional.

No final de 1997, o Brasil adotou medidas rígidas de ajuste fiscal e monetário, com o objetivo de coibir a perda de reservas cambiais e de manter a confiança dos investidores externos. Esperava-se um declínio no nível das atividades econômicas do principal membro do bloco. Tal fato não aconteceu, e o desaquecimento da economia brasileira foi brando, não causando impacto sobre os outros países membros do bloco.

80 Univ. Rel. Int., Brasília, v. 5, n. 1/2, p. 67-95, jan./dez. 2007 
Em 1998, o impacto da crise asiática sobre o nível de atividades dos quatro países que compõem o Mercosul foi, igualmente, bem mais ameno do que se esperava, segundo as previsões elaboradas no final de 1997.

\section{As exportações brasileiras totais e as exportações para o Mercosul}

No ano de 1990, no que tange ao comércio regional, 3.834 empresas brasileiras exportaram para os países do atual bloco, perfazendo um valor total de US\$ 1.540 milhões, sendo que as destinações dos principais produtos brasileiros exportados foram:

a. Argentina: minério de ferro aglomerado, minério de ferro, laminado plano (ferro-aço), acessórios para automóveis, ônibus e caminhões e óxido de propileno;

b. Paraguai: pneumáticos para ônibus e caminhões, óleo diesel, tecido de algodão, adubo/fertilizantes, tratores agrícolas e cerveja de malte, em latas;

c. Uruguai: polietileno dens. $<0,94$, mate cancheado, central de comutação automática para telefonia, automóveis de passageiros com motor a gasolina, tratores agrícolas e camioneta/furgão.

No que concerne às importações brasileiras no mesmo ano, os principais produtos importados foram:

a. Argentina: trigo em grãos, milho em grãos, massas frescas, azeitona conservada, carne de bovino e pêras frescas;

b. Paraguai: algodão, carne de bovino, óleo de "mentha arvensis", sementes de rícino, madeira de pau-marfim e bovinos para corte;

c. Uruguai: outras peças de bovino, arroz semibranqueado, couro/pele bovino, carne de bovino, malte inteiro ou partido e pneumáticos.

A criação do Mercosul propiciou expansão e diversificação da produção de empresas exportadoras, bem como atraiu a implantação de novas para tal mercado. Já em 2001, o número de empresas exportadoras para o 
Mercosul aumentou para 11.436. Elas exportaram um total de US\$ 5.476 milhões, valor este que decresceu nos últimos três anos. O incremento, de produção e exportação empresarial, ocorreu, por ordem, nas seguintes regiões: Sudeste, Sul, Nordeste, Centro-Oeste e Norte.

As empresas exportadoras estão localizadas em diversos municípios do país, com maior concentração nas regiões Sudeste e Sul. Com a diversificação da produção, o impacto fez-se sentir na renda e no consumo das pessoas e no nível educacional, à medida que, cada vez mais, as empresas necessitavam de mão-de-obra qualificada. Pôde-se observar uma tendência ao aumento das exportações brasileiras para esse mercado.

Para melhor compreensão do crescimento do comércio do Brasil no âmbito do Mercosul, as tabelas abaixo apresentam as exportações totais brasileiras e o crescimento das exportações para o bloco integracionista. Quanto às exportações totais, as regiões Sudeste e Sul continuaram sendo as maiores exportadoras do país.

\section{Tabela 1}

\begin{tabular}{|c|c|c|c|c|c|c|c|c|c|c|c|c|}
\hline \multicolumn{13}{|c|}{ EXPORTAÇÕES BRASILEIRAS POR U. F. EM US\$ (milhões) FOB DEFLACIONADAS PELO IPC - EUA (1995=100) } \\
\hline UF & 1990 & 1991 & 1992 & 1993 & 1994 & 1995 & 1996 & 1997 & 1998 & 1999 & 2000 & 2001 \\
\hline REGIÃO NORTE & 2092,2 & 1966,0 & 1982,7 & 2133,8 & 2136,9 & 2433,1 & 2333,0 & 2441,3 & 2422,9 & 2449,0 & 2939,6 & 2789,7 \\
\hline ACRE & 3,1 & 2,5 & 2,1 & 4,3 & 4,3 & 5,2 & 2,4 & 0,2 & 0,8 & 1,2 & 1,4 & 5,0 \\
\hline AMAPÁ & 64,2 & 59,7 & 10,2 & 59,0 & 75,9 & 65,8 & 98,6 & 60,9 & 58,3 & 41,2 & 31,9 & 26,2 \\
\hline AMAZONAS & 208,3 & 119,6 & 160,7 & 152,8 & 137,7 & 138,3 & 139,9 & 183,7 & 248,8 & 392,9 & 683,8 & 732,6 \\
\hline PARÁ & 1805,4 & 1762,1 & 1787,3 & 1878,8 & 1871,9 & 2181,4 & 2056,9 & 2149,4 & 2065,0 & 1954,0 & 2160,3 & 1970,0 \\
\hline RONDÔNIA & 11,0 & 21,9 & 18,2 & 31,9 & 37,6 & 37,8 & 27,0 & 35,5 & 35,2 & 50,9 & 52,7 & 48,8 \\
\hline RORAIMA & 0,2 & 0,3 & 3,8 & 6,9 & 5,8 & 4,4 & 6,9 & 2,5 & 2,3 & 1,6 & 2,3 & 3,8 \\
\hline REGIÃO NORDESTE & 3534,3 & 3199,8 & 3296,0 & 3177,9 & 3601,1 & 4240,0 & 3745,1 & 3760,0 & 3478,0 & 3069,5 & 3561,5 & 3600,9 \\
\hline ALAGOAS & 339,9 & 304,6 & 264,4 & 250,9 & 247,7 & 468,1 & 281,0 & 323,5 & 272,7 & 205,8 & 198,5 & 262,0 \\
\hline BAHIA & 1695,0 & 1455,6 & 1619,5 & 1529,9 & 1768,9 & 1919,2 & 1793,6 & 1773,0 & 1710,2 & 1446,4 & 1719,4 & 1824,2 \\
\hline CEARÁ & 268,9 & 302,6 & 329,7 & 289,9 & 344,3 & 352,1 & 369,6 & 335,2 & 332,1 & 339,6 & 438,1 & 453,6 \\
\hline MARANHÃO & 516,2 & 533,4 & 464,2 & 488,0 & 591,9 & 671,4 & 662,1 & 706,9 & 594,5 & 606,5 & 671,0 & 468,4 \\
\hline PARAÍBA & 61,3 & 62,7 & 64,2 & 73,8 & 86,0 & 86,1 & 100,4 & 82,5 & 50,6 & 57,3 & 68,6 & 90,6 \\
\hline PERNAMBUCO & 467,1 & 376,8 & 382,7 & 364,6 & 383,2 & 574,3 & 331,3 & 353,7 & 338,6 & 243,2 & 251,3 & 288,3 \\
\hline PIAUI & 37,8 & 44,8 & 42,9 & 68,0 & 55,2 & 67,1 & 60,7 & 58,8 & 55,0 & 45,0 & 56,1 & 34,5 \\
\hline RIO GRANDE DO NORTE & 103,6 & 89,7 & 79,2 & 85,7 & 89,2 & 79,2 & 92,2 & 88,8 & 95,1 & 105,6 & 132,2 & 161,4 \\
\hline REGIÃO CENTRO-OESTE & 657,2 & 642,5 & 758,9 & 835,0 & 1150,6 & 986,5 & 1343,7 & 1703,6 & 1135,4 & 1184,0 & 1622,0 & 2130,7 \\
\hline DISTRITO FEDERAL & 3,4 & 4,9 & 11,5 & 5,9 & 10,6 & 6,8 & 30,0 & 7,6 & 4,6 & 8,2 & 1,4 & 9,8 \\
\hline GOIÁS & 235,8 & 266,1 & 236,4 & 262,2 & 363,0 & 248,7 & 376,0 & 451,6 & 356,8 & 298,1 & 482,1 & 512,1 \\
\hline MATO GROSSO & 296,2 & 250,2 & 337,6 & 347,6 & 479,1 & 426,3 & 640,5 & 880,1 & 610,1 & 678,0 & 914,4 & 1201,2 \\
\hline IVAFA ERQSSQ QQ SUL & Ela胫高 & $2 \mathcal{2}^{21}, 3$ & एPस7\$,4 & 219,2 & 298,0 & 304,8 & 297,1 & 364,3 & 164,0 & 199,7 & 224,0 & 407,6 \\
\hline REGIAOSUDESTE & 21954,9 & 21781,2 & 23478,3 & 23474,7 & 25738,1 & 26634,7 & 25943,8 & 28104,3 & 28051,5 & 25625,3 & 27547,2 & 27112,7 \\
\hline ESPIRITO SANBOC & blescass & exg50 & rtareoes & Do44si & eq́prost & 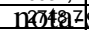 & Se238tut & 292914 & 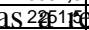 & 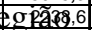 & 2470,1 & 2090,5 \\
\hline MINAS GERAIS & 5364,9 & 5418,9 & 5243,9 & 5278,8 & 5853,1 & 5860,7 & 5625,5 & 6861,7 & 7095,9 & 5838,3 & 5938,6 & 5204,8 \\
\hline RIO DE JANEIRO & 1696,4 & 1968,2 & 2055,4 & 2226,1 & 2369,5 & 2057,6 & 1830,7 & 1646,4 & 1666,1 & 1501,0 & 1627,8 & 2068,6 \\
\hline בान人 & 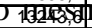 & 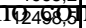 & 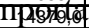 & 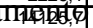 & 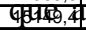 & 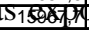 & 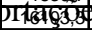 & 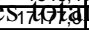 & S1 & a1क्षण & 17510,8 & 17748,9 \\
\hline REGIÃO SUL & 7892,7 & 7397,2 & 8947,7 & 10398,4 & 11245,4 & 11401,0 & 12189,6 & 13225,2 & 11649,5 & 10519,0 & 11401,1 & 12643,3 \\
\hline PARANÁ & 2178,8 & 2022,1 & 2291,5 & 2617,3 & 3605,1 & 3567,3 & 4125,0 & 4608,3 & 3952,4 & 3597,5 & 3886,7 & 4576,2 \\
\hline RIO GRANDE DO SUL & 4014,3 & 3685,9 & 4712,5 & 5462,4 & 5168,1 & 5181,7 & 5502,4 & 5953,4 & 5261,6 & 4572,9 & 5114,8 & 5460,8 \\
\hline 82 SANTIAOAATARANA & nf16983 & 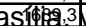 & V 543,8 & 23187 & $674 \pi 9$ & 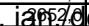 & ez25ळ2 & 772663,6 & 2435,5 & 2348,6 & 2399,7 & 2606,2 \\
\hline OUTROS* & 505,6 & 393,1 & 407,4 & 650,0 & 894,6 & 810,9 & 831,9 & 1075,0 & 1069,0 & 1074,2 & 1675,2 & 1829,0 \\
\hline BRASIL & 36637,0 & 35379,8 & 38871,0 & 40669,9 & 44766,8 & 46506,3 & 46387,1 & 50309,3 & 47806,3 & 43921,1 & 48746,6 & 50106,4 \\
\hline
\end{tabular}


de retração de 1998 e 1999. O fenômeno deveu-se aos acréscimos nas exportações do estado do Amazonas nesse mesmo período.

Enquanto o estado do Amazonas e, principalmente, o de Mato Grosso estavam, a cada ano, descobrindo vocação exportadora, aumentando, no período acima analisado, suas exportações em 251,7\% e 305,54\%, respectivamente, os estados do Amapá e de Sergipe retraíram suas exportações em 59,19\% e 59,87\%, respectivamente.

No caso do Mercosul, verifica-se que, desde a sua criação, há uma crescente participação de todas as regiões, com a exportação para esse mercado, como pode ser observado na tabela 2.

\section{Tabela 2}

\begin{tabular}{|c|c|c|c|c|c|c|c|c|c|c|c|c|}
\hline \multicolumn{13}{|c|}{ EXPORTAÇÕES PARA O MERCOSUL POR U. F. EM US\$ (milhões) FOB DEFLACIONADAS PELO IPC - EUA (1995=100) } \\
\hline UF & 1990 & 1991 & 1992 & 1993 & 1994 & 1995 & 1996 & 1997 & 1998 & 1999 & 2000 & 2001 \\
\hline REGIÃO NORTE & 26,3 & 38,8 & 61,7 & 79,2 & 46,8 & 53,3 & 61,8 & 97,1 & 150,0 & 140,7 & 327,3 & 276,6 \\
\hline ACRE & 0,0 & 0,0 & 0,0 & 0,0 & 0,0 & 0,0 & 0,0 & 0,1 & 0,0 & 0,3 & 0,8 & 0,7 \\
\hline AMAPÁ & 7,2 & 3,6 & 0,1 & 2,0 & 2,7 & 2,1 & 1,4 & 2,1 & 2,5 & 1,8 & 0,9 & 0,3 \\
\hline AMAZONAS & 9,5 & 14,7 & 37,5 & 34,6 & 15,5 & 21,8 & 36,3 & 55,0 & 80,6 & 91,6 & 277,4 & 234,5 \\
\hline PARÁ & 9,5 & 20,3 & 22,8 & 40,3 & 26,1 & 27,0 & 21,0 & 31,7 & 58,7 & 39,1 & 41,5 & 34,7 \\
\hline RONDÓNIA & 0,0 & 0,2 & 1,4 & 2,4 & 2,6 & 2,4 & 3,0 & 8,2 & 8,0 & 7,8 & 6,6 & 6,3 \\
\hline RORAIMA & 0,0 & 0,0 & 0,0 & 0,0 & 0,0 & 0,0 & 0,0 & 0,0 & 0,0 & 0,0 & 0,0 & 0,0 \\
\hline TOCANTINS & 0,0 & 0,0 & 0,0 & 0,0 & 0,0 & 0,0 & 0,0 & 0,0 & 0,1 & 0,1 & 0,0 & 0,1 \\
\hline REGIÁO NORDESTE & 112,4 & 157,2 & 214,9 & 247,4 & 330,3 & 420,7 & 468,5 & 508,6 & 500,8 & 392,1 & 426,0 & 369,3 \\
\hline ALAGOAS & 0,0 & 3,9 & 0,5 & 1,1 & 12,3 & 0,6 & 8,3 & 9,7 & 6,7 & 0,7 & 2,4 & 1,5 \\
\hline $\mathrm{BAHIA}$ & 94,5 & 109,2 & 148,9 & 149,6 & 195,3 & 287,1 & 299,5 & 332,9 & 318,9 & 242,4 & 260,6 & 220,1 \\
\hline CEARA & 5,3 & 10,5 & 12,7 & 28,6 & 31,6 & 43,2 & 49,9 & 50,2 & 59,2 & 50,4 & 52,7 & 46,8 \\
\hline MARANHĀO & 0,1 & 3,3 & 20,3 & 29,0 & 35,5 & 38,4 & 48,9 & 47,4 & 43,6 & 37,1 & 50,9 & 49,2 \\
\hline PARAÍBA & 1,1 & 2,2 & 0,9 & 2,9 & 3,2 & 7,1 & 4,1 & 9,4 & 11,2 & 10,5 & 7,9 & 3,2 \\
\hline PERNAMBUCO & 8,4 & 19,5 & 23,5 & 26,9 & 45,8 & 36,7 & 39,1 & 40,6 & 38,8 & 36,6 & 34,7 & 35,0 \\
\hline PIAUII & 0,5 & 1,2 & 0,5 & 0,6 & 0,4 & 1,4 & 0,7 & 1,6 & 2,1 & 0,7 & 0,8 & 0,6 \\
\hline RIO GRANDE DO NORTE & 0,3 & 0,6 & 2,6 & 3,6 & 2,2 & 2,5 & 4,5 & 8,1 & 12,3 & 7,9 & 6,8 & 6,6 \\
\hline SERGIPE & 2,1 & 6,8 & 4,8 & 5,1 & 3,9 & 3,8 & 13,5 & 8,7 & 7,8 & 5,9 & 9,3 & 6,3 \\
\hline REGIÃO CENTRO-OESTE & 14,1 & 27,7 & 33,0 & 40,2 & 39,5 & 62,1 & 75,7 & 101,3 & 86,6 & 72,1 & 64,8 & 65,2 \\
\hline DISTRITO FEDERAL & 0,0 & 0,0 & 0,0 & 0,0 & 0,0 & 0,0 & 0,0 & 0,0 & 0,0 & 0,1 & 0,2 & 0,2 \\
\hline GOIÁS & 3,1 & 5,2 & 10,6 & 21,1 & 20,4 & 23,3 & 22,1 & 25,9 & 16,9 & 18,2 & 15,1 & 21,7 \\
\hline MATO GROSSO & 1,1 & 1,8 & 4,9 & 6,0 & 3,0 & 3,4 & 7,8 & 13,0 & 9,7 & 14,7 & 10,5 & 8,8 \\
\hline MATO GROSSO DO SUL & 9,9 & 20,7 & 17,5 & 13,1 & 16,0 & 35,4 & 45,8 & 62,4 & 59,9 & 39,0 & 39,0 & 34,4 \\
\hline REGIĀO SUDESTE & 1.070 & 1.822 & 3.268 & 3.956 & 4.218 & 4.123 & 4.763 & 5.802 & 5.570 & 3.956 & 4.122 & 3.189 \\
\hline ESPÍRITO SANTO & 60,9 & 62,7 & 63,3 & 81,4 & 135,0 & 157,4 & 117,1 & 153,5 & 106,6 & 71,9 & 82,2 & 53,2 \\
\hline MINAS GERAIS & 143,6 & 292,5 & 572,2 & 632,7 & 564,2 & 487,9 & 509,7 & 785,2 & 754,3 & 424,2 & 454,3 & 453,0 \\
\hline RIO DE JANEIRO & 120,5 & 187,3 & 294,2 & 386,0 & 387,7 & 317,2 & 299,3 & 321,1 & 283,5 & 256,2 & 245,9 & 243,8 \\
\hline SÄO PAULO & 744,9 & $1.279,7$ & $2.338,2$ & $2.856,2$ & $3.131,5$ & $3.161,0$ & $3.836,8$ & $4.541,9$ & $4.425,6$ & $3.204,0$ & $3.339,4$ & $2.438,8$ \\
\hline REGIÄO SUL & 311 & 523 & 861 & 1.329 & 1.391 & 1.363 & 1.676 & 1.992 & 1.920 & 1.551 & 1.802 & 1.485 \\
\hline PARANÁ & 90,0 & 146,4 & 245,4 & 382,2 & 370,4 & 337,7 & 438,8 & 498,5 & 463,5 & 407,5 & 550,5 & 449,3 \\
\hline RIO GRANDE DO SUL & 160,5 & 248,1 & 407,3 & 640,6 & 724,1 & 709,9 & 870,4 & $1.030,9$ & $1.036,7$ & 799,6 & 882,3 & 720,5 \\
\hline SANTA CATARINA & 60,4 & 128,8 & 208,5 & 306,4 & 296,7 & 315,5 & 367,1 & 462,6 & 419,4 & 343,8 & 369,1 & 315,0 \\
\hline OUTROS* & 6,2 & 14,8 & 11,1 & 30,2 & 61,5 & 131,1 & 52,2 & 87,5 & 72,6 & 88,4 & 101,5 & 91,9 \\
\hline BRASIL & 1.540 & 2.584 & 4.450 & 5.682 & 6.088 & 6.154 & 7.097 & 8.588 & 8.300 & 6.200 & 6.843 & 5.477 \\
\hline
\end{tabular}

Fonte: SECEX. Elaboração: IPEA

Nas exportações para o Mercosul, destacam-se os estados do Amazonas e do Maranhão, que modificaram sua situação, anteriormente pouco representativas. O Amazonas, em 2001, passou a ser responsável por Univ. Rel. Int., Brasília, v. 5, n. 1/2, p. 67-95, jan./dez. 2007 
85\% das exportações da região Norte para o Mercosul. No mesmo ano, o Maranhão, que, em 1990, era o penúltimo estado do Nordeste em valor exportado para o Mercosul, à frente apenas de Alagoas, passou a ser, nesse âmbito, o segundo maior exportador daquela região.

Com a implementação do Mercosul, era esperado o aumento das exportações brasileiras para esse mercado, como ocorreu, de modo geral, em todo o Brasil, até 1997.

\section{As exportações brasileiras totais e as exportações para 0 Mercosul.}

Para propiciar uma visão mais clara do crescimento do comércio do Brasil no que concerne ao Mercosul, encontram-se, abaixo, tabelas, nas quais, as exportações totais brasileiras e o crescimento das exportações para o bloco integracionista foram detalhadas. Pode-se inferir que a criação desse comércio acarretou fatores como incremento da produção interna, melhorias nos meios de produção, aproveitamento crescente de mãode-obra qualificada e não qualificada, o que impacta o nível de renda e o mercado doméstico.

Importa reiterar que as regiões Sudeste e Sul permaneceram, quanto às exportações totais, na condição de maiores exportadoras do país. 


\section{Tabela 1 - Exportações brasileiras por U. F. em US\$ milhões FOB, deflac. Pelo IPC - EUA (1995 =-100)}

\begin{tabular}{|c|c|c|c|c|c|c|c|c|c|c|c|c|}
\hline \multicolumn{13}{|c|}{ EXPORTAÇÕES BRASILEIRAS POR U. F. EM US\$ (milhões) FOB DEFLAC. PELO IPC - EUA (1995=100) } \\
\hline UF & 1990 & 1991 & 1992 & 1993 & 1994 & 1995 & 1996 & 1997 & 1998 & 1999 & 2000 & 2001 \\
\hline REGIÃO NORTE & 2092,2 & 1966,0 & 1982,7 & 2133,8 & 2136,9 & 2433,1 & 2333,0 & 2441,3 & 2422,9 & 2449,0 & 2939,6 & 2789,7 \\
\hline ACRE & 3,1 & 2,5 & 2,1 & 4,3 & 4,3 & 5,2 & 2,4 & 0,2 & 0,8 & 1,2 & 1,4 & 5,0 \\
\hline AMAPÁ & 64,2 & 59,7 & 10,2 & 59,0 & 75,9 & 65,8 & 98,6 & 60,9 & 58,3 & 41,2 & 31,9 & 26,2 \\
\hline AMAZONAS & 208,3 & 119,6 & 160,7 & 152,8 & 137,7 & 138,3 & 139,9 & 183,7 & 248,8 & 392,9 & 683,8 & 732,6 \\
\hline PARÁ & 1805,4 & 1762,1 & 1787,3 & 1878,8 & 1871,9 & 2181,4 & 2056,9 & 2149,4 & 2065,0 & 1954,0 & 2160,3 & 1970,0 \\
\hline RONDÔNIA & 11,0 & 21,9 & 18,2 & 31,9 & 37,6 & 37,8 & 27,0 & 35,5 & 35,2 & 50,9 & 52,7 & 48,8 \\
\hline RORAIMA & 0,2 & 0,3 & 3,8 & 6,9 & 5,8 & 4,4 & 6,9 & 2,5 & 2,3 & 1,6 & 2,3 & 3,8 \\
\hline TOCANTINS & 0,0 & 0,0 & 0,4 & 0,2 & 3,8 & 0,2 & 1,4 & 9,3 & 12,5 & 7,3 & 7,4 & 3,4 \\
\hline REGIÃO NORDESTE & 3534,3 & 3199,8 & 3296,0 & 3177,9 & 3601,1 & 4240,0 & 3745,1 & 3760,0 & 3478,0 & 3069,5 & 3561,5 & 3600,9 \\
\hline ALAGOAS & 339,9 & 304,6 & 264,4 & 250,9 & 247,7 & 468,1 & 281,0 & 323,5 & 272,7 & 205,8 & 198,5 & 262,0 \\
\hline BAHIA & 1695,0 & 1455,6 & 1619,5 & 1529,9 & 1768,9 & 1919,2 & 1793,6 & 1773,0 & 1710,2 & 1446,4 & 1719,4 & 1824,2 \\
\hline CEARÁ & 268,9 & 302,6 & 329,7 & 289,9 & 344,3 & 352,1 & 369,6 & 335,2 & 332,1 & 339,6 & 438,1 & 453,6 \\
\hline MARANHĀO & 516,2 & 533,4 & 464,2 & 488,0 & 591,9 & 671,4 & 662,1 & 706,9 & 594,5 & 606,5 & 671,0 & 468,4 \\
\hline PARAÍBA & 61,3 & 62,7 & 64,2 & 73,8 & 86,0 & 86,1 & 100,4 & 82,5 & 50,6 & 57,3 & 68,6 & 90,6 \\
\hline PERNAMBUCO & 467,1 & 376,8 & 382,7 & 364,6 & 383,2 & 574,3 & 331,3 & 353,7 & 338,6 & 243,2 & 251,3 & 288,3 \\
\hline PIAUI & 37,8 & 44,8 & 42,9 & 68,0 & 55,2 & 67,1 & 60,7 & 58,8 & 55,0 & 45,0 & 56,1 & 34,5 \\
\hline RIO GRANDE DO NORTE & 103,6 & 89,7 & 79,2 & 85,7 & 89,2 & 79,2 & 92,2 & 88,8 & 95,1 & 105,6 & 132,2 & 161,4 \\
\hline SERGIPE & 44,6 & 29,6 & 49,2 & 27,1 & 34,9 & 22,5 & 54,4 & 37,6 & 29,2 & 20,1 & 26,3 & 17,9 \\
\hline REGIĀO CENTRO-OESTE & 657,2 & 642,5 & 758,9 & 835,0 & 1150,6 & 986,5 & 1343,7 & 1703,6 & 1135,4 & 1184,0 & 1622,0 & 2130,7 \\
\hline DISTRITO FEDERAL & 3,4 & 4,9 & 11,5 & 5,9 & 10,6 & 6,8 & 30,0 & 7,6 & 4,6 & 8,2 & 1,4 & 9,8 \\
\hline GOIAS & 235,8 & 266,1 & 236,4 & 262,2 & 363,0 & 248,7 & 376,0 & 451,6 & 356,8 & 298,1 & 482,1 & 512,1 \\
\hline MATO GROSSO & 296,2 & 250,2 & 337,6 & 347,6 & 479,1 & 426,3 & 640,5 & 880,1 & 610,1 & 678,0 & 914,4 & 1201,2 \\
\hline MATO GROSSO DO SUL & 121,8 & 121,3 & 173,4 & 219,2 & 298,0 & 304,8 & 297,1 & 364,3 & 164,0 & 199,7 & 224,0 & 407,6 \\
\hline REGIÂO SUDESTE & 21954,9 & 21781,2 & 23478,3 & 23474,7 & 25738,1 & 26634,7 & 25943,8 & 28104,3 & 28051,5 & 25625,3 & 27547,2 & 27112,7 \\
\hline ESPIRITO SANTO & 1650,0 & 1895,6 & 1800,0 & 1844,0 & 2366,1 & 2748,7 & 2384,4 & 2418,2 & 2251,5 & 2238,6 & 2470,1 & 2090,5 \\
\hline MINAS GERAIS & 5364,9 & 5418,9 & 5243,9 & 5278,8 & 5853,1 & 5860,7 & 5625,5 & 6861,7 & 7095,9 & 5838,3 & 5938,6 & 5204,8 \\
\hline RIO DE JANEIRO & 1696,4 & 1968,2 & 2055,4 & 2226,1 & 2369,5 & 2057,6 & 1830,7 & 1646,4 & 1666,1 & 1501,0 & 1627,8 & 2068,6 \\
\hline SÃO PAULO & 13243,6 & 12498,5 & 14379,0 & 14125,7 & 15149,4 & 15967,7 & 16103,3 & 17177,9 & 17038,0 & 16047,3 & 17510,8 & 17748,9 \\
\hline$\overline{R E G I A ̂ A}$ & 7892,7 & 7397,2 & 8947,7 & 10398,4 & 11245,4 & 11401,0 & 12189,6 & 13225,2 & 11649,5 & 10519,0 & 11401,1 & 12643,3 \\
\hline PARANA & 2178,8 & 2022,1 & 2291,5 & 2617,3 & 3605,1 & 3567,3 & 4125,0 & 4608,3 & 3952,4 & 3597,5 & 3886,7 & 4576,2 \\
\hline RIO GRANDE DO SUL & 4014,3 & 3685,9 & 4712,5 & 5462,4 & 5168,1 & 5181,7 & 5502,4 & 5953,4 & 5261,6 & 4572,9 & 5114,8 & 5460,8 \\
\hline SANTA CATARINA & 1699,7 & 1689,3 & 1943,8 & 2318,7 & 2472,2 & 2652,0 & 2562,2 & 2663,6 & 2435,5 & 2348,6 & 2399,7 & 2606,2 \\
\hline OUTROS* & 505,6 & 393,1 & 407,4 & 650,0 & 894,6 & 810,9 & 831,9 & 1075,0 & 1069,0 & 1074,2 & 1675,2 & 1829,0 \\
\hline BRASIL & 36637,0 & 35379,8 & 38871,0 & 40669,9 & 44766,8 & 46506,3 & 46387,1 & 50309,3 & 47806,3 & 43921,1 & 48746,6 & 50106,4 \\
\hline
\end{tabular}

Verifica-se que, desde a criação do Mercosul, há uma crescente participação de todas as regiões na exportação para esse mercado, como pode ser observado na tabela 2.

Observando a relação entre as exportações totais brasileiras e as destinadas para o Mercosul, verifica-se que a participação deste nas vendas externas brasileiras vem possibilitando sua incrementação de forma substancial, chegando a representar $17 \%$ das vendas externas do país em 1997 e $11 \%$ em 2001, . 
Tabela 2 - Exportações para o Mercosul por U.F. em US\$ milhões FOB deflac. pelo IPC - EUA (1995 = 100)

\begin{tabular}{|c|c|c|c|c|c|c|c|c|c|c|c|c|}
\hline \multicolumn{13}{|c|}{ EXPORTAÇÕES PARA O MERCOSUL POR U. F. EM US\$ (milhões) FOB DEFLAC. PELO IPC - EUA (1995=100) } \\
\hline UF & 1990 & 1991 & 1992 & 1993 & 1994 & 1995 & 1996 & 1997 & 1998 & 1999 & 2000 & 2001 \\
\hline REGIÂO NORTE & 26,3 & 38,8 & 61,7 & 79,2 & 46,8 & 53,3 & 61,8 & 97,1 & 150,0 & 140,7 & 327,3 & 276,6 \\
\hline ACRE & 0,0 & 0,0 & 0,0 & 0,0 & 0,0 & 0,0 & 0,0 & 0,1 & 0,0 & 0,3 & 0,8 & 0,7 \\
\hline AMAPÁ & 7,2 & 3,6 & 0,1 & 2,0 & 2,7 & 2,1 & 1,4 & 2,1 & 2,5 & 1,8 & 0,9 & 0,3 \\
\hline AMAZONAS & 9,5 & \begin{tabular}{l|l}
14,7 \\
\end{tabular} & 37,5 & 34,6 & 15,5 & 21,8 & 36,3 & 55,0 & 80,6 & 91,6 & 277,4 & 234,5 \\
\hline$\overline{\text { PARA }}$ & 9,5 & 20,3 & 22,8 & 40,3 & 26,1 & 27,0 & 21,0 & 31,7 & 58,7 & 39,1 & 41,5 & 34,7 \\
\hline RONDÔNIA & 0,0 & 0,2 & 1,4 & 2,4 & 2,6 & 2,4 & 3,0 & 8,2 & 8,0 & 7,8 & 6,6 & 6,3 \\
\hline RORAIMA & 0,0 & 0,0 & 0,0 & 0,0 & 0,0 & 0,0 & 0,0 & 0,0 & 0,0 & 0,0 & 0,0 & 0,0 \\
\hline TOCANTINS & 0,0 & 0,0 & 0,0 & 0,0 & 0,0 & 0,0 & 0,0 & 0,0 & 0,1 & 0,1 & 0,0 & $\overline{0,1}$ \\
\hline REGIÂOO NORDESTE & 112,4 & 157,2 & 214,9 & 247,4 & 330,3 & 420,7 & 468,5 & 508,6 & 500,8 & 392,1 & 426,0 & 369,3 \\
\hline ALAGOAS & 0,0 & 3,9 & 0,5 & 1,1 & 12,3 & 0,6 & 8,3 & 9,7 & 6,7 & 0,7 & 2,4 & 1,5 \\
\hline BAHIA & 94,5 & 109,2 & 148,9 & 149,6 & 195,3 & 287,1 & 299,5 & 332,9 & 318,9 & 242,4 & 260,6 & 220,1 \\
\hline CEARÁ & 5,3 & 10,5 & 12,7 & 28,6 & 31,6 & 43,2 & 49,9 & 50,2 & 59,2 & 50,4 & 52,7 & 46,8 \\
\hline MARANHĀO & 0,1 & 3,3 & 20,3 & 29,0 & 35,5 & 38,4 & 48,9 & 47,4 & 43,6 & 37,1 & 50,9 & 49,2 \\
\hline PARAÍBA & 1,1 & 2,2 & 0,9 & 2,9 & 3,2 & 7,1 & 4,1 & 9,4 & 11,2 & 10,5 & 7,9 & 3,2 \\
\hline PERNAMBUCO & 8,4 & 19,5 & 23,5 & 26,9 & 45,8 & 36,7 & 39,1 & 40,6 & 38,8 & 36,6 & 34,7 & 35,0 \\
\hline PIAUI & 0,5 & 1,2 & 0,5 & 0,6 & 0,4 & 1,4 & 0,7 & 1,6 & 2,1 & 0,7 & 0,8 & 0,6 \\
\hline RIO GRANDE DO NORTE & 0,3 & 0,6 & 2,6 & 3,6 & 2,2 & 2,5 & 4,5 & 8,1 & 12,3 & 7,9 & 6,8 & $\overline{6,6}$ \\
\hline SERGIPE & 2,1 & 6,8 & 4,8 & 5,1 & 3,9 & 3,8 & 13,5 & 8,7 & 7,8 & 5,9 & 9,3 & 6,3 \\
\hline REGIÂO CENTRO-OESTE & 14,1 & 27,7 & 33,0 & 40,2 & 39,5 & 62,1 & 75,7 & 101,3 & 86,6 & 72,1 & 64,8 & 65,2 \\
\hline DISTRITO FEDERAL & 0,0 & 0,0 & 0,0 & 0,0 & 0,0 & 0,0 & 0,0 & 0,0 & 0,0 & 0,1 & 0,2 & 0,2 \\
\hline GOIÁS & 3,1 & 5,2 & 10,6 & 21,1 & 20,4 & 23,3 & 22,1 & 25,9 & 16,9 & 18,2 & 15,1 & 21,7 \\
\hline MATO GROSSO & 1,1 & 1,8 & 4,9 & 6,0 & 3,0 & 3,4 & 7,8 & 13,0 & 9,7 & 14,7 & 10,5 & 8,8 \\
\hline MATO GROSSO DO SUL & 9,9 & 20,7 & 17,5 & 13,1 & 16,0 & 35,4 & 45,8 & 62,4 & 59,9 & 39,0 & 39,0 & $\overline{34,4}$ \\
\hline REGIÃO SUDESTE & 069,9 & 822,2 & $3.268,0$ & $.956,3$ & $4.218,4$ & $.123,5$ & $.762,9$ & $5.801,8$ & $5.569,9$ & $3.956,3$ & $4.121,8$ & $3.188,8$ \\
\hline ESPIRITO SANTO & 60,9 & 62,7 & 63,3 & 81,4 & 135,0 & 157,4 & 117,1 & 153,5 & 106,6 & 71,9 & 82,2 & 53,2 \\
\hline MINAS GERAIS & 43,6 & 292,5 & 572,2 & 632,7 & 564,2 & 487,9 & 509,7 & 785,2 & 754,3 & 424,2 & 454,3 & 453,0 \\
\hline RIO DE JANEIRO & 120,5 & 187,3 & 294,2 & 386,0 & 387,7 & 317,2 & 299,3 & 321,1 & 283,5 & 256,2 & 245,9 & 243,8 \\
\hline SĀO PAULO & 744,9 & $1.279,7$ & $2.338,2$ & $2.856,2$ & $3.131,5$ & $3.161,0$ & $3.836,8$ & $4.541,9$ & $4.425,6$ & $3.204,0$ & $3.339,4$ & $2.438,8$ \\
\hline REGIÃO SUL & 310,9 & 523,2 & 861,2 & $1.329,2$ & $1.391,1$ & $1.363,0$ & $1.676,2$ & $1.992,0$ & $1.919,7$ & $1.550,9$ & $1.801,9$ & $1.484,8$ \\
\hline PARANÁ & 0,0 & 46,4 & 245,4 & 382,2 & 370,4 & 337,7 & 438,8 & 498,5 & 463,5 & 407,5 & 550,5 & 449,3 \\
\hline RIO GRANDE DO SUL & 160,5 & 248,1 & 407,3 & 640,6 & 724,1 & 709,9 & 870,4 & $1.030,9$ & $1.036,7$ & 799,6 & 882,3 & 720,5 \\
\hline SANTA CATARINA & 60,4 & 128,8 & 208,5 & 306,4 & 296,7 & 315,5 & 367,1 & 462,6 & 419,4 & 343,8 & 369,1 & 315,0 \\
\hline OUTROS* & 6,2 & 14,8 & 11,1 & 30,2 & 61,5 & 131,1 & 52,2 & 87,5 & 72,6 & 88,4 & 101,5 & 91,9 \\
\hline BRASIL & $1.539,8$ & $2.583,9$ & $4.449,8$ & $5.682,4$ & $6.087,6$ & $6.153,8$ & $7.097,3$ & $8.588,2$ & $8.299,5$ & $6.200,4$ & $6.843,2$ & $5.476,6$ \\
\hline
\end{tabular}

Fonte SECEX. Elaboração IPEA 


\section{Gráfico 01}

Exportações Brasileiras para o Mercosul por Região (em milhões de

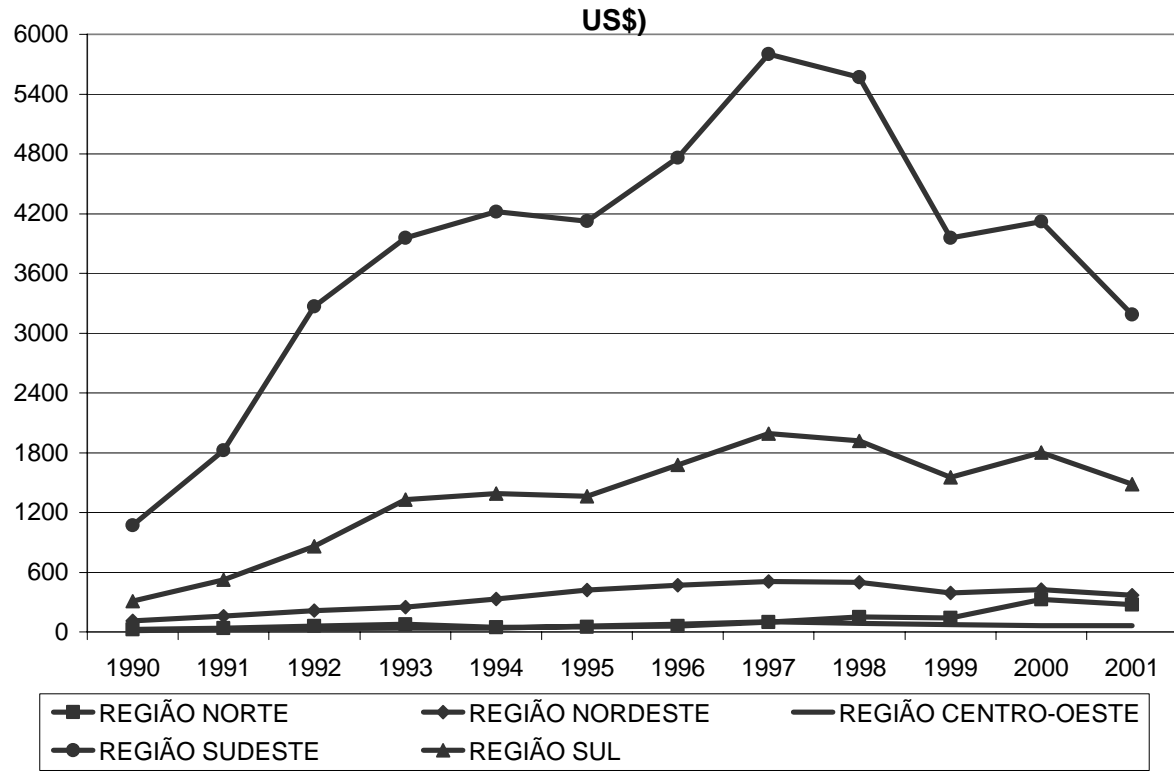

Fonte: SECEX. Elaboração: IPEA 
O comércio no âmbito do Mercosul

\section{Gráfico 02}

Estados Brasileiros que mais exportaram para o Mercosul (em milhões de US\$)

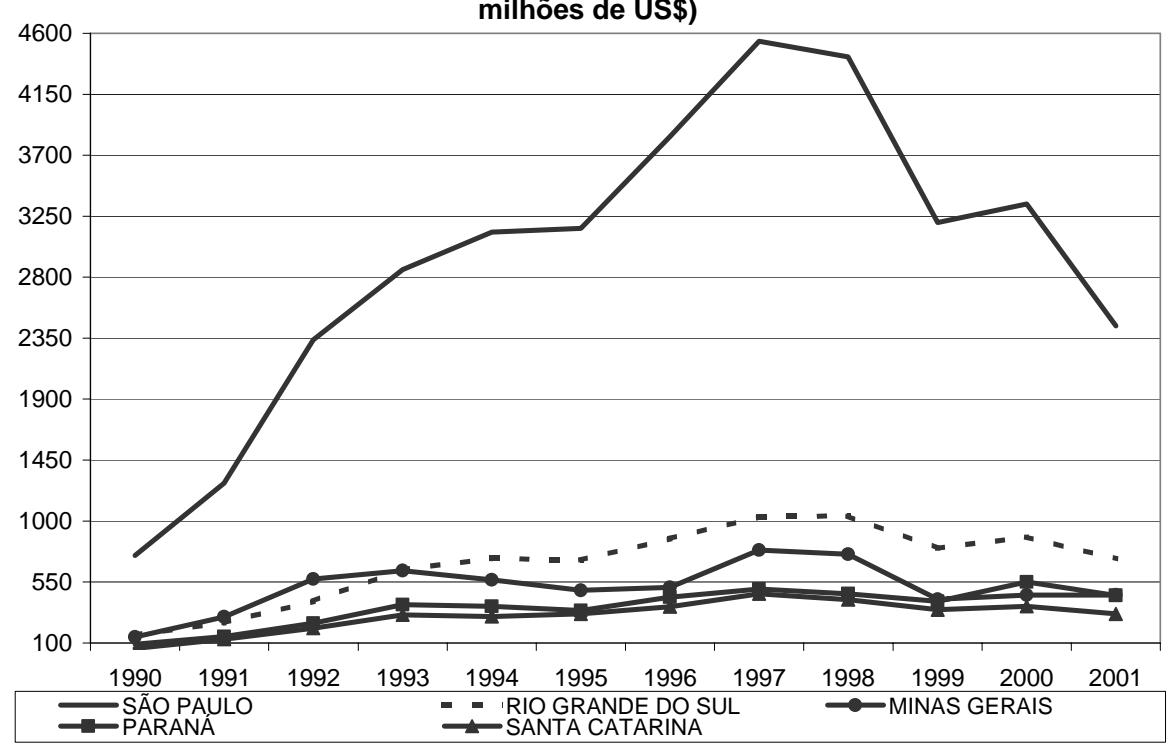

Fonte: Secex. Elaboração: IPEA 
Tabela 3

\begin{tabular}{|c|c|c|c|c|c|c|c|c|c|c|c|c|}
\hline \multicolumn{13}{|c|}{ Relação Exportações Brasileiras para o Mercosul e Exportações Brasileiras Totais } \\
\hline UF & 1990 & 1991 & 1992 & 1993 & 1994 & 1995 & 1996 & 1997 & 1998 & 1999 & 2000 & 2001 \\
\hline REGIÃO NORTE & 1,3 & 2,0 & 3,1 & 3,7 & 2,2 & 2,2 & 2,6 & 4,0 & 6,2 & 5,7 & 11,1 & 9,9 \\
\hline ACRE & 0,0 & 0,2 & 0,0 & 0,4 & 0,0 & 0,0 & 1,5 & 32,7 & 0,0 & 25,6 & 59,8 & 13,7 \\
\hline AMAPÁ & 11,3 & 6,0 & 0,7 & 3,3 & 3,5 & 3,2 & 1,4 & 3,4 & 4,3 & 4,5 & 3,0 & 1,1 \\
\hline AMAZONAS & 4,6 & 12,3 & 23,3 & 22,6 & 11,2 & 15,8 & 26,0 & 29,9 & 32,4 & 23,3 & 40,6 & 32,0 \\
\hline PARA & 0,5 & 1,2 & 1,3 & 2,1 & 1,4 & 1,2 & 1,0 & 1,5 & 2,8 & 2,0 & 1,9 & 1,8 \\
\hline RONDÖNIA & 0,3 & 0,8 & 7,5 & 7,5 & 7,0 & 6,3 & 11,1 & 23,2 & 22,8 & 15,3 & 12,6 & 12,9 \\
\hline RORAIMA & 0,0 & 0,0 & 0,0 & 0,0 & 0,2 & 0,0 & 0,0 & 0,0 & 0,0 & 0,0 & 0,0 & 0,0 \\
\hline TOCANTINS & 0,0 & 0,0 & 0,0 & 0,0 & 0,0 & 0,0 & 0,2 & 0,5 & 0,6 & 0,7 & 0,0 & 3,7 \\
\hline REGIÃO NORDESTE & 3,2 & \begin{tabular}{|l|l|}
4,9 & \\
\end{tabular} & \begin{tabular}{l|l}
6,5 & \\
\end{tabular} & \begin{tabular}{l|l|}
7,8 & \\
\end{tabular} & \begin{tabular}{l|l}
9,2 \\
\end{tabular} & 9,9 & 12,5 & 13,5 & 14,4 & 12,8 & 12,0 & 10,3 \\
\hline ALAGOAS & 0,0 & 1,3 & 0,2 & 0,4 & 5,0 & 0,1 & 3,0 & 3,0 & 2,4 & 0,3 & 1,2 & 0,6 \\
\hline BAHIA & 5,6 & 7,5 & 9,2 & 9,8 & 11,0 & 15,0 & 16,7 & 18,8 & 18,6 & 16,8 & 15,2 & 12,1 \\
\hline CEARÁ & 2,0 & 3,5 & 3,9 & 9,8 & 9,2 & 12,3 & 13,5 & 15,0 & 17,8 & 14,8 & 12,0 & 10,3 \\
\hline MARANHÃO & 0,0 & 0,6 & 4,4 & 5,9 & 6,0 & 5,7 & 7,4 & 6,7 & 7,3 & 6,1 & 7,6 & 10,5 \\
\hline PARAÍBA & 1,8 & 3,6 & 1,4 & 4,0 & 3,7 & 8,2 & 4,1 & 11,4 & 22,2 & 18,3 & 11,5 & 3,6 \\
\hline PERNAMBUCO & 1,8 & 5,2 & 6,1 & 7,4 & 12,0 & 6,4 & 11,8 & 11,5 & 11,5 & 15,1 & 13,8 & 12,1 \\
\hline PIAUI & 1,4 & 2,8 & 1,2 & 0,9 & 0,8 & 2,0 & 1,2 & 2,7 & 3,9 & 1,5 & 1,3 & 1,8 \\
\hline RIO GRANDE DO NORTE & 0,3 & 0,6 & 3,3 & 4,2 & 2,5 & 3,1 & 4,8 & 9,1 & 12,9 & 7,5 & 5,2 & 4,1 \\
\hline SERGIPE & 4,8 & 23,1 & 9,8 & 19,0 & 11,1 & 16,9 & 24,7 & 23,2 & 26,9 & 29,4 & 35,3 & 35,2 \\
\hline REGIÃO CENTRO-OESTE & 2,1 & 4,3 & 4,4 & 4,8 & 3,4 & 6,3 & 5,6 & 5,9 & 7,6 & 6,1 & 4,0 & 3,1 \\
\hline DISTRITO FEDERAL & 0,0 & 0,0 & 0,0 & 0,3 & 0,0 & 0,0 & 0,1 & 0,5 & 0,9 & 1,6 & 14,5 & 2,3 \\
\hline GOIÁS & 1,3 & 1,9 & 4,5 & 8,0 & 5,6 & 9,4 & 5,9 & 5,7 & 4,7 & 6,1 & 3,1 & 4,2 \\
\hline MATO GROSSO & 0,4 & 0,7 & 1,4 & 1,7 & 0,6 & 0,8 & 1,2 & 1,5 & 1,6 & 2,2 & 1,1 & 0,7 \\
\hline MATO GROSSO DO SUL & 8,2 & 17,1 & 10,1 & 6,0 & 5,4 & 11,6 & 15,4 & 17,1 & 36,6 & 19,5 & 17,4 & 8,4 \\
\hline REGIÃO SUDESTE & 4,9 & 8,4 & 13,9 & 16,9 & 16,4 & 15,5 & 18,4 & 20,6 & 19,9 & 15,4 & 15,0 & 11,8 \\
\hline ESPÍRITO SANTO & 3,7 & 3,3 & 3,5 & 4,4 & 5,7 & 5,7 & 4,9 & 6,3 & 4,7 & 3,2 & 3,3 & 2,5 \\
\hline MINAS GERAIS & 2,7 & 5,4 & 10,9 & 12,0 & 9,6 & 8,3 & 9,1 & 11,4 & 10,6 & 7,3 & 7,6 & 8,7 \\
\hline RIO DE JANEIRO & 7,1 & 9,5 & 14,3 & 17,3 & 16,4 & 15,4 & 16,3 & 19,5 & 17,0 & 17,1 & 15,1 & 11,8 \\
\hline SÃO PAULO & 5,6 & 10,2 & 16,3 & 20,2 & 20,7 & 19,8 & 23,8 & 26,4 & 26,0 & 20,0 & 19,1 & 13,7 \\
\hline REGIÃO SUL & 3,9 & 7,1 & 9,6 & 12,8 & 12,4 & 12,0 & 13,8 & 15,1 & 16,5 & 14,7 & 15,8 & 11,7 \\
\hline PARANÁ & 4,1 & 7,2 & 10,7 & 14,6 & 10,3 & 9,5 & 10,6 & 10,8 & 11,7 & 11,3 & 14,2 & 9,8 \\
\hline RIO GRANDE DO SUL & 4,0 & 6,7 & 8,6 & 11,7 & 14,0 & 13,7 & 15,8 & 17,3 & 19,7 & 17,5 & 17,2 & 13,2 \\
\hline SANTA CATARINA & 3,6 & 7,6 & 10,7 & 13,2 & 12,0 & 11,9 & 14,3 & 17,4 & 17,2 & 14,6 & 15,4 & 12,1 \\
\hline OUTROS* $^{*}$ & 1,2 & 3,8 & 2,7 & 4,6 & 6,9 & 16,2 & 6,3 & 8,1 & 6,8 & 8,2 & 6,1 & 5,0 \\
\hline BRASIL & 4,2 & 7,3 & 11,4 & 14,0 & 13,6 & 13,2 & 15,3 & 17,1 & 17,4 & 14,1 & 14,0 & 10,9 \\
\hline
\end{tabular}

Fonte: Secex. laboração: IPEA

\section{Conclusão}

O MERCOSUL foi instituído em 1991, sendo que, em 1990, apenas 3.384 empresas exportadoras brasileiras participavam das vendas para os países que, posteriormente, formaram o bloco integracionista. Em 2001, o número de empresas exportadoras para esse mercado elevou-se para 11.436 unidades.

A consolidação de um bloco requer um período de maturação do acordo. Requer, ainda, fatores políticos estratégicos, adequação das políticas macroeconômicas nacionais em função da integração, adaptação de políticas tarifárias, livre circulação de mão-de-obra, tradição comercial e aproximação gradual entre os países etc. Porém, o principal aspecto refere-se à criação de comércio. 
Nesse sentido, a participação de novas empresas exportadoras brasileiras vem aumentando num ritmo crescente, o que demonstra, numa primeira instância, o incremento da produção interna para atender à nova demanda do bloco integracionista, bem como um fluxo comercial ascendente no mercado regional. Pode-se inferir que tal fato influenciou positivamente tanto a economia doméstica quanto as economias dos países da região.

O incremento no número das empresas brasileiras exportadoras para o mercado regional aponta para alterações na economia doméstica. Isso no que concerne: ao melhor uso de insumos importados e de recursos naturais do país; à geração de empregos e de demanda por mão-de-obra especializada; ao uso intensivo de tecnologias, mais diversificadas também; à geração de renda; à ampliação de mercado; e à melhoria na qualidade de vida da população, tal como prevê a teoria da integração.

Do ponto de vista espacial, como foi demonstrado no trabalho, as regiões brasileiras que mais participaram com suas empresas nas vendas para o Mercado Regional foram a Sudeste e o Sul.

Observa-se que à proporção que medidas de promoção e de aprimoramento do bloco integracionista foram adotadas, mais empresas sentiram-se atraídas por participar no novo mercado. Os produtos comercializados, igualmente, diversificaram-se. Observa-se uma complementaridade, sobretudo, na indústria automotiva. Essa complementaridade industrial é um dos objetivos do Mercosul. Note-se, ainda, que a diversificação de produtos negociados no Mercosul deverá continuar acontecendo, gradualmente associada a maior aproximação entre os países membros. Tal aproximação fará com que os países empenhem seus esforços produtivos em bens que atendam à demanda do mercado regional. Os aspectos microeconômicos do Mercosul estão associados, neste trabalho, à empresa individual, que tende a se especializar quando participa do 
comércio internacional, considerando que uma concorrência mais forte faz parte desse mercado.

Outro aspecto a ser destacado diz respeito à expansão ou à implantação de empresas exportadoras para o Mercosul. Nos municípios brasileiros onde isso aconteceu, ocorreram benéficas mudanças na economia local, fazendo elevar-se, sobretudo, o nível de instrução dos empregados dessas empresas, com repercussões positivas nos salários (salvo algumas exceções).

Os incrementos das vendas no Mercosul repercutiram, diretamente, no aprimoramento do nível instrucional do país. Tal fato está associado às novas tecnologias, necessárias para o processo produtivo, e implica um processo de absorção tecnológica por parte dos países membros, o que vem, em primeira instância, beneficiar as economias da região.

Foi possível observar que o incremento do comércio provocou, também, alterações na pauta de exportações brasileiras para o Mercosul, com a diversificação de produtos comercializados e com a participação crescente de municípios de todas as regiões do país.

No que tange às importações brasileiras do bloco integracionista, observa-se uma alteração substantiva das importações do bloco. Há uma constante diversificação dos importados, sobretudo no que concerne à indústria automotiva, e isso aponta para uma complementação industrial, atendendo, de certa forma, a um dos objetivos do acordo.

Outro aspecto a ser ressaltado é o fato de o transporte ser um facilitador para as empresas exportadoras no caso do Mercosul, por ser este uma integração regional em terras contínuas. Para essas empresas, não há custos com transporte marítimo, armazenagem, representações, alguns tributos, burocracia alfandegária etc., diferentemente do que ocorre quando elas exportam para outros continentes. 
Com a expansão gradual do comércio no âmbito do Mercosul, verificam-se tendências para modificações estruturais nos países que o compõem, desde a logística até um maior uso de tecnologia no setor produtivo. Isso repercute diretamente na qualidade de vida da população da região.

A crescente participação de empresas brasileiras no Mercosul tem contribuído, positivamente, com a economia doméstica. Observam-se tendências a maiores impactos à medida que propostas dinâmicas para o mercado regional forem implantadas, sobretudo, com o reaquecimento da economia Argentina.

Ainda deve ser considerado o pouco tempo de existência do mercado regional, mas resultados positivos vêm sendo alcançados em relação a esse comércio, além da conquista de uma presença forte no cenário internacional.

Segundo os dados analisados, conclui-se que são necessárias, principalmente, a adoção e a implementaçãode políticas estratégicas para um incremento comercial do Mercosul e projeção maior do bloco. Como demonstrado, as empresas exportadoras apresentam crescente tendência de participação, com suas vendas, nesse mercado regional. O aumento dessas vendas tem um impacto direto no número de funcionários e nas novas tecnologias com repercussões imediatas no bem-estar.

Deve ser destacado, ainda, o aprimoramento contínuo da mãode-obra das empresas exportadoras para o Mercosul, em função do incremento do nível tecnológico, acarretando melhorias no valor agregado dos exportados. Esse incremento do conteúdo tecnológico dos exportados, considerando o uso intensivo de fatores de produção nacionais e de insumos importados, gera mais riqueza para o país e permite, assim, que se alcance 
um dos objetivos da integração que é a melhoria da qualidade de vida da população.

Este trabalho permite vários desdobramentos, desde a parte social, formação de clusters industriais até o uso de instrumentos de promoção de exportações, aspectos que deverão ser analisados em futuras investigações.

\section{Commerce in Mercosul}

\section{Abstract}

One of the main objectives concerning market integration refers to commerce creation, which is carried on by enterprises. These enterprises will get specialization trough the use of new technologies and labour specialization in order to be in accordance with the new supply. In this work it will be presented the increasing of Brazilian exporters enterprises to Marcos, their exports evolution in FOB value, the dynamic of employees quantity as well as their instructions level and salaries in these enterprises. The analysis was carried out at country, states and cities level where these firms carried on their activities. This enterprise dynamic benefits the Brazilian economy related to improvements in the production sector, to intrafirm relations, to more efficient use of national and imported inputs as well as labour specialization promoting in this way the well fare. These aspects demonstrate how Mercosur became and will be important in the future for Brazilian Economy.

Commerce - Mercosul - Brazilian Economy

\section{Referências}

ARAGÃO, José Maria. A harmonização de políticas macroeconômicas no MERCOSUL. Buenos Aires: BID/Intal, 1993. 
ARGENTINA. Ministry of Economy and Public Work and Services. Secretary of Trade and Investment. Growing with Argentina in Mercosur. Buenos Aires, 2002.

BACKS, D.K., e KELHOE, P. International evidence on the historical properties of business cycles. The American Economic Review, [S.l.], v. 82, issue 4, 1992.

BALASSA, Bela. Teoria da integração econômica. 1972.

BAUMANN, Renato (Org.). MERCOSUL: avanços e desafios da integração. Brasília: IPEA/CEPAL, 2001.

BRASIL. Ministério da Indústria, do Comércio e do Turismo; Secretaria de Política Industrial. Políticas de Apoio as MPMEs do Mercosul: proposta brasileira. Brasília, 2000. Revisão do documento.

BRASIL. MRE. DECLA. Coletânea de informações sobre o Mercosul. Brasília, 1992

BRASIL. MRE. Departamento de Promoção Comercial. Blocos econômicos: Mercosul. Brasília, 1997.

BID. INTAL. Informe Mercosul. Buenos Aires, 1998.

BIZELLI E BARBOSA, João dos Santos e Ricardo. TEC Mercosul: O que você precisa saber sobre as últimas alterações no comércio exterior. s.n 2001

BRANDÃO, A . S.; VALLS, L. Mercosul perspectivas da integração. Rio de Janeiro: Fundação Getúlio Vargas, 1996

FLORÊNCIO, S. A; ARAÚJO, E. H. F. Mercosul hoje. São Paulo: AlfaOmega, 1996.

GUIMARÃES, E. P. Componente tecnológico comparativo das exportações ao Mercosul e ao resto do mundo. TD, [S.l.], n. 765. out. 2000.

HUMMELS, D. E; KLENOW, P. The variety and quality of a nation's trade. 2002. (Working Paper, n. 8712).

INFORME BANCO DO BRASIL. Comércio Exterior. Edição n¹5. 1997. 
INSTITUTE FOR EUROPEAN - LATIN AMERICA RELATIONS. Irela. El MERCOSUL: perspectivas de un bloque emergente.1997.

KEOHANE, Robert O. After hegemony cooperation and discord in the world political economy. New Jersey: Princeton University Press, 1984.

MERCOSUL: informações selecionadas. Brasília: Banco Central do Brasil, 1991.

MINISTERIO DA INDUSTRIA, DO COMERCIO E DO TURISMO; SECRETARIA DE POLÍTICA INDUSTRIAL. Propuestas de politicas de apoyo a las micro, pequeñas y medianas empresas del MERCOSUR. Brasília, 1994.

PROFISSIONAIS ESTRANGEIROS SE MULTIPLICAM NO BRASIL, Revista do Mercosul, n 6, Jan-2001.

A VOLTA DO PROTECIONISMO, Revista do Mercosul, n 37, Jun-1995.

RIO GRANDE DO SUL. Secretaria do Desenvolvimento Econômico e Social. Exportações: Mercosul. Porto Alegre, 1994.

VENTURA, D. .F. L. (Org.). O Mercosul em movimento. Porto Alegre: Livraria do Advogado, 1995. (Série integração latino-americana). 